\title{
Perancangan dan Implementasi Elearning Pada Matakuliah Logika Fuzzy
}

\author{
Gunawan $^{1 *}$, Richki Hardi ${ }^{2}$ \\ ${ }^{1,2}$ Universitas Mulia \\ "gunawan@universitasmulia.ac.id
}

\begin{abstract}
The goal of e-learning in fuzzy logic courses is to help students learn by creating menu structures and simple operation techniques, as well as prototypes for e-learning in fuzzy logic courses. The difficulty that students have in putting what they have learned into practice stems from the fact that the introduction of e-learning can make it easier for students to access material that they do not understand. The research approach in this study was an analytic learning prototype. In this fuzzy logic course, the outcomes of e-learning products based on online apps can be used as learning material. This e-menu learning's structure consists of a home page with an introduction to e-learning, a site page with participants, calendars, and notes, and a notes page. The most important aspects of e-learning are pages that can be used to expand the network and courses. Material, discussion, forums, quizzes, and other activities are all part of e-learning. The results of the validation by media specialists on this e-learning application are favorable, indicating that it is fit for use. The material used is excellent, according to the results of material expert validation, implying that it is ideal for use in fuzzy logic courses. The limited test results for students enrolled in the Informatics study program were in the very good category, indicating that this e-learning tool was simple to use.
\end{abstract}

Keywords: design of e-learning, fuzzy logic, implementation learning

\begin{abstract}
Abstrak
Tujuan e-learning pada mata kuliah logika fuzzy adalah untuk membantu mahasiswa belajar dengan membuat struktur menu dan teknik operasi sederhana, serta prototipe untuk e-learning pada mata kuliah logika fuzzy. Kesulitan siswa dalam mempraktekkan apa yang telah mereka pelajari bermula dari kenyataan bahwa pengenalan e-learning dapat memudahkan siswa untuk mengakses materi yang tidak mereka pahami. Pendekatan penelitian dalam penelitian adalah prototype pembelajaran analitik. Pada mata kuliah logika fuzzy, hasil produk e-learning berbasis aplikasi online dapat dijadikan sebagai bahan pembelajaran. Struktur pembelajaran e-menu terdiri dari halaman home dengan pengenalan e-learning, halaman situs peserta, kalender, dan catatan, dan halaman catatan. Aspek terpenting dari e-learning adalah halaman yang dapat digunakan untuk memperluas jaringan dan kursus. Materi, diskusi, forum, kuis, dan kegiatan lainnya merupakan bagian dari e-learning. Hasil validasi ahli media pada aplikasi e-learning tersebut cukup baik, menunjukkan layak untuk digunakan. Materi yang digunakan sangat baik, menurut hasil validasi ahli materi, menyiratkan sangat ideal untuk digunakan pada mata kuliah logika fuzzy. Hasil tes terbatas untuk mahasiswa yang terdaftar di program studi Informatika berada pada kategori sangat baik, menunjukkan bahwa alat e-learning tersebut mudah digunakan.
\end{abstract}

Kata kunci: perancangan e-learning, logika fuzzy, implementasi pembelajaran

\section{Pendahuluan}

Teknologi internet berkembang pesat dan telah merambah ke setiap sudut dunia. Tersebut digunakan oleh banyak negara, institusi, dan spesialis untuk berbagai tujuan, termasuk pendidikan [1]. Belajar diartikan sebagai guru dan siswa bekerja sama untuk mencapai tujuan tertentu [2]. Harus ada tujuan, bahan ajar, prosedur, dan penilaian yang merupakan satu kesatuan yang tidak dapat dipisahkan. Pasal 31 ayat (2) UndangUndang Nomor 20 Tahun 2003 tentang Sistem Pendidikan Nasional mengatur bahwa pendidikan jarak jauh bertujuan untuk memberikan pelayanan pendidikan kepada kelompok masyarakat yang tidak dapat 
mengikuti pengajaran tatap muka atau reguler. Penegasan tersebut diulangi dalam Pasal 31 ayat (2) Undang-Undang Nomor 12 Tahun 2012. Pendidikan jarak jauh berupaya untuk memperluas akses dan memfasilitasi pendidikan tinggi dalam proses belajar mengajar, di samping menawarkan layanan pendidikan tinggi kepada kelompok masyarakat yang tidak dapat hadir secara tatap muka. -muka atau sekolah biasa.

Sedangkan menurut Peraturan Pemerintah Republik Indonesia Nomor 17 Tahun 2010 tentang Pengelolaan dan Penyelenggaraan Pendidikan (pasal 118 ayat 1), pendidikan jarak jauh bertujuan untuk memperluas dan pemerataan pendidikan serta meningkatkan mutu dan relevansi pendidikan. Selanjutnya, Pasal 2 Peraturan Menteri Pendidikan dan Kebudayaan Republik Indonesia Nomor 24 Tahun 2012 tentang Penyelenggaraan Pendidikan Jarak Jauh di Perguruan Tinggi menyatakan bahwa pendidikan jarak jauh bertujuan untuk meningkatkan perluasan dan pemerataan akses pendidikan yang bermutu. pendidikan yang relevan sesuai kebutuhan.

Sedangkan menurut Peraturan Pemerintah Republik Indonesia Nomor 17 Tahun 2010 tentang Pengelolaan dan Penyelenggaraan Pendidikan (pasal 118 ayat 1), pendidikan jarak jauh bertujuan untuk meningkatkan perluasan dan pemerataan akses pendidikan serta meningkatkan relevansi mutu pendidikan. Dengan demikian, Pasal 2 Peraturan Menteri Pendidikan dan Kebudayaan Republik Indonesia Nomor 24 Tahun 2012 tentang Penyelenggaraan Pendidikan Jarak Jauh di Perguruan Tinggi menyatakan bahwa pendidikan jarak jauh bertujuan untuk meningkatkan perluasan dan pemerataan akses terhadap mutu yang relevan. pendidikan sesuai kebutuhan. Elearning dideftersebutsikan sebagai setiap pengajaran dan pembelajaran yang menggunakan sirkuit elektronik untuk memberikan konten pembelajaran, interaksi, atau arah [4].

Siswa lebih mudah untuk belajar ketika mereka memiliki akses ke internet [5]. Karena kesulitan dalam mengadopsi pembelajaran jarak jauh yang ada, pengguna jarang menggunakannya [6]. Menurut data mahasiswa Prodi Informatika, dari 100 mahasiswa, beberapa mata kuliah harus menggunakan pembelajaran jarak jauh atau online, yang lebih banyak berisi teori daripada praktik. Mahasiswa pada mata kuliah logika fuzzy 60 memilih untuk tampil secara online karena dapat mempermudah dan mempercepat akses, khususnya pada materi yang menjelaskan teori dan contoh kerja. Sebanyak 25 siswa tidak setuju dengan adanya pembelajaran jarak jauh online karena tidak bisa langsung bertanya kepada dosen jika ada pertanyaan. Karena kedua modalitas belajar tersebut terhubung, 15 siswa lainnya membutuhkannya.

Faktor lain yang menyebabkan mahasiswa tersebut menentang pembelajaran jarak jauh antara lain jaringan internet yang terbatas, peralatan komputer, smartphone, kamera, audio, dll. Pengembangan e-learning kursus logika fuzzy tersebut membuat konten yang dipelajari mudah dipahami. Terdapat contoh dan ilustrasi dari setiap materi yang ditawarkan dalam e-learning tersebut, seperti film tentang materi logika fuzzy. Framework dan Bootstrap adalah paket perangkat lunak yang digunakan. Software tersebut memiliki berbagai keunggulan, antara lain sebagai berikut: memiliki kemampuan yang sangat lengkap, tampilan desain yang logis, dan dapat digunakan di semua jenjang sekolah. Untuk mengikuti pembelajaran daring juga diperlukan keuletan, kedisiplinan, kemandirian, dan tingkat tanggung jawab yang tinggi terhadap segala peraturan yang berlaku dalam pengajaran tersebut. Apalagi jika kursus online yang ditempuh berasal dari negara lain. Tentu saja, juga perlu fasih berbahasa Inggris. Karena konten yang ditawarkan seringkali cukup padat, terutama jika mengarah pada pemahaman topik yang lebih baik. Pengertian berbagi sumber belajar telah diadopsi dan ditingkatkan sepanjang beberapa dekade sebelumnya dengan menggunakan media teknologi informasi seperti Electronic Learning, Virtual Learning, Mobile Learning, dan sebagainya [8].

E-Learning secara umum mengacu pada Kursus Online dengan sejumlah besar pendaftaran terbuka yang mencakup layanan dan materi admtersebutstrasi penerimaan, desain [9], titik akses, metode aplikasi, dan deftersebutsi keberhasilan [10]. Teknologi 
elearning adalah kegemaran pembelajaran online terbaru dan alternatif yang layak untuk program pendidikan tinggi tradisional [11].

Setelah kejadian tersebut, E-learning telah membawa transformasi di sektor pendidikan dalam waktu singkat, membuka prospek pedagogi baru dan model bisnis [12], menyediakan ribuan siswa dengan pendidikan berkualitas tinggi yang dapat diakses. Karena akses terbuka tersebut, orang-orang dari seluruh dunia dapat mendaftar di E-learning [13]. Dokumen, rekaman video, dan teknologi lainnya digunakan dalam e-learning untuk menyampaikan materi kursus atau pelatihan kepada siswa dalam jumlah tak terbatas setiap saat. Tidak ada batasan pada kehadiran siswa atau persyaratan pelatihan. Kursus logika fuzzy, seperti E-learning pada umumnya, menggunakan sumber belajar berbasis web, sistem penilaian online, laboratorium online, pelatihan dan pendampingan instruktur, dan tes persiapan untuk mendapatkan Sertifikat Standar Industri [14]. Sebagai mahasiswa yang mengikuti kursus online, saya menyadarkan masyarakat bahwa belajar di kelas online tidak sesederhana yang diperkirakan sebelumnya. Tersebut jauh lebih menantang daripada sekadar merancang dan menyiapkan kursus online untuk siswa. Mengingat semua bahan ajar tersedia secara online, dibutuhkan keuletan, disiplin waktu [15], kemandirian, dan rasa tanggung jawab yang kuat untuk mempelajari konten dan menyelesaikan tugas (tugas dan tes) yang diperlukan sebelum menerima sertifikat kelulusan [16] .

\section{Metoda Penelitian}

Metode yang digunakan dalam penelitian tersebut adalah Learning Analytic Prototype, yaitu dengan melakukan beberapa langkah atau tahapan sebagai berikut:

a) Identifikasi kebutuhan pengguna. Diskusi diadakan untuk menentukan kebutuhan pengguna antara dosen dan mahasiswa pada tahap tersebut. Pengguna dapat menggambarkan kebutuhan sistem yang tepat dan diinginkan.

b) Membuat desain prototipe. Pada tahap tersebut, peneliti membuat prototipe kebutuhan sistem yang diinginkan. c) Pengujian Prototipe. Pada tahap tersebut pengguna dapat menguji sistem e-learning yang telah disediakan, dan pengguna dapat memberikan saran atau masukan.

d) Memperbaiki Prototipe. Pada tahap tersebut peneliti melakukan perbaikan dan modifikasi sesuai dengan masukan pengguna.

e) Implementasi. Setelah dilakukan evaluasi dan sistem sesuai dengan keinginan pengguna. Kemudian sistem tersebut dapat diimplementasikan pada mata kuliah logika fuzzy.

Sebuah model yang dapat diterapkan dalam mata kuliah e-learning fuzzy sebagai berikut:

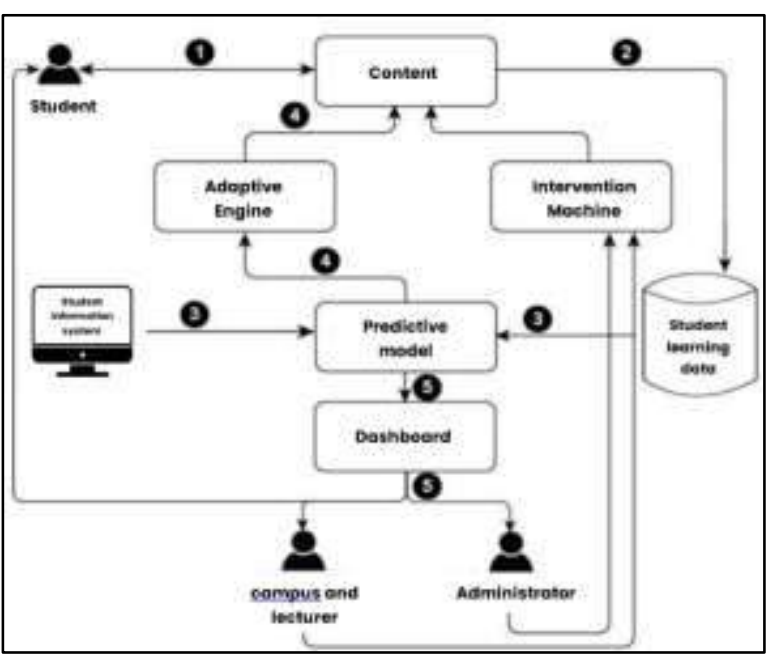

Gambar 1. Penerapan Model Sistem Pembelajaran Learning Analytics

Proses pembelajaran yang dilakukan dengan menggunakan bantuan sistem pembelajaran online mendukung penggalian data siswa selama proses pembelajaran. Data tersebut diolah menggunakan LA, yang kemudian digunakan untuk menyempurnakan proses PBM. Implementasi LA dalam model sistem pembelajaran adaptif meliputi 6 (enam) komponen utama, yang dapat dilihat pada Gambar 1.

1) Pengelola konten: membantu siswa dalam menyediakan konten dan alat penilaian untuk mendukung proses pembelajaran

2) Data belajar siswa: menyimpan semua catatan aktivitas dan perilaku siswa selama berinteraksi dalam sistem 
3) Model Prediktif: menggabungkan data demografi dan perilaku siswa sehingga dapat digunakan untuk melacak kemajuan belajar siswa untuk memprediksi kinerja masa depan mereka dan berbagai potensi masalah yang mungkin dihadapi;

4) dasbor: Menggunakan keluaran Model Prediktif untuk disajikan dalam dasbor yang mudah dipahami pengguna lain.

5) Adaptive Engine: memanfaatkan informasi dari hasil Model Prediktif untuk memilih bahan ajar yang dapat disesuaikan dengan kebutuhan dan kinerja siswa dalam berbagai tingkat kondisi; dan

6) Mesin Intervensi: membantu guru/instruktur, admtersebutstrator, dan pengembang sistem dalam mengambil alih sistem otomatis untuk kebutuhan belajar siswa dalam konteks tertentu

\section{Hasil Penelitian}

\subsection{Hasil}

Mahasiswa yang berniat menggunakan e-learning tersebut harus mendaftar sebagai pengguna untuk mengaksesnya. Pengguna dibagi menjadi tiga kategori: pengguna, admtersebutstrator, dan profesor. Pengguna pada topik tersebut adalah mahasiswa yang mengikuti mata kuliah logika fuzzy yang hanya dapat mengakses materi, mengerjakan soal, dan bertanya di forum. Pengguna admin berfungsi sebagai manajemen e-learning dengan memeriksa, memelihara, dan meningkatkan layanan, antara lain. Pengguna dosen situs web tersebut mengatur sumber daya, memberikan tugas, mengelola nilai, menyediakan daftar kehadiran siswa, dan terlibat dalam obrolan online. Sumber daya dan aktivitas adalah dua komponen mendasar dari e-learning. Sumber daya mencakup sumber daya instruksional dalam berbagai format, sedangkan kegiatan mencakup kegiatan yang dapat digunakan siswa. Bahasa Indonesia dan Bahasa Inggris adalah bahasa yang digunakan dalam e-learning tersebut. Dalam e-learning yang digunakan, siswa dapat memilih bahasa penyampaiannya. Validasi ahli diperlukan untuk produk yang telah dirancang agar sistem aplikasi tersebut dapat digunakan. Instrumen untuk menilai kinerja sistem diperlukan untuk memverifikasi profesional media. Ada 15 item penilaian dalam instrumen penilaian. Hasil validasi ahli media mendapat skor 60 dan tergolong sangat baik.

Sistem pembelajaran yang telah lolos hasil validasi ahli media dan ahli materi dan dapat digunakan kemudian dilanjutkan ke tahap uji coba terbatas. Pengujian dilakukan terhadap 100 mahasiswa program studi logika fuzzy program studi informatika. Hasil pengujian menghasilkan skor rata-rata 80 pada kriteria luar biasa, yang menunjukkan bahwa sistem e-learning tersebut mudah digunakan.

\subsection{Pembahasan}

Karena program e-learning tersebut bertempat di server universitas, pengguna hanya perlu memasukkan alamat email dan kata sandi. Pengguna tidak perlu menginstal atau mengelola menu yang rumit karena semuanya sudah siap digunakan dan mudah diatur sesuai kebutuhan. Jadi membuat elearning tidaklah sulit; siapa pun bisa melakukannya. Sebelum membuat e-learning, beberapa peralatan, seperti komputer/laptop dan akses internet serta berbagai kamera dan perangkat audio, harus disediakan. Homepage, halaman menu, dan pilihan materi merupakan area menu yang sangat signifikan dalam e-learning tersebut. Pengguna dipandu ke isi e-learning, gambaran umum mata kuliah yang akan dipelajari, dan sebagainya. Selain menu home tersebut terdapat logo universitas, menu utama, bahasa yang akan digunakan pada website, navigasi, gambaran umum materi yang akan dipelajari, dan lain sebagainya. Pengguna yang mengikuti kursus, kalender, catatan, berita, dan halaman yang dapat digunakan untuk mengembangkan jaringan semua dapat ditemukan di halaman menu. Menu konteks adalah yang paling signifikan karena menu pada menu tersebut memungkinkan siswa untuk mengakses materi yang akan mereka pelajari. Mahasiswa dapat berkomunikasi dengan sesama mahasiswa atau dosen selain materi pada menu tersebut. Materi yang dapat dilihat dapat dimasukkan dalam berbagai format, 
namun peneliti hanya menyertakan format ppt, pdf, dan video untuk pengujian tersebut. Kuis, chatting, forum, presentasi online, dan kegiatan lainnya adalah beberapa yang dapat dilakukan dalam e-learning. Siswa didorong untuk berinteraksi dengan konten yang akan dipelajari.

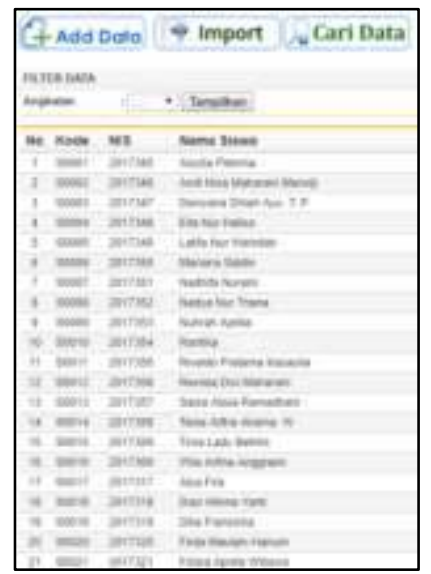

Gambar 2. Proses manajemen pembelajaran logika fuzzy (1)

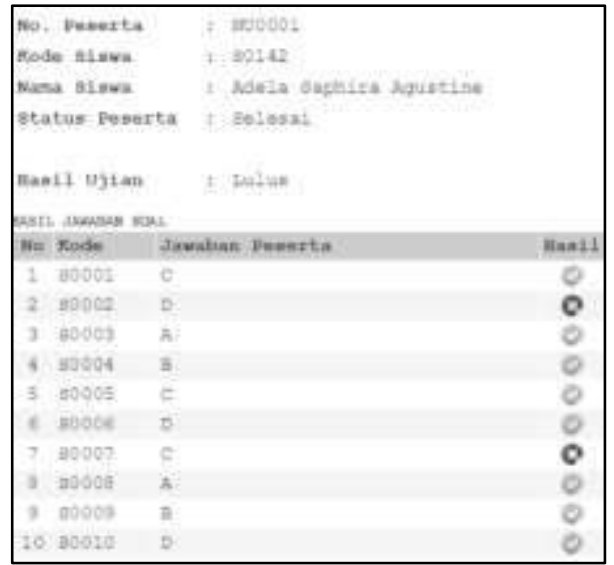

Gambar 3. Proses manajemen pembelajaran logika fuzzy (2)

Membangun e-learning memerlukan kegiatan interaktif antara mahasiswa dan dosen, seperti chatting, forum diskusi, dan virtual meet. Hasil validasi ahli media menunjukkan bahwa produk akhir dapat digunakan. Untuk membuat e-learning yang menarik dan menarik, tiga kriteria yang harus dipenuhi ketika membangun e-learning: sederhana, personal, dan cepat [17]. Dalam pembuatan elearning tersebut peneliti memadatkan navigasi menjadi tiga bagian utama yaitu home, site page, dan course. Karena bahasa yang digunakan atau pesan yang ditransmisikan tidak disampaikan secara efektif, komunikasi tidak menerima nilai total; untuk mengatasi hal tersebut agar lebih komunikatif, peneliti memperbaikinya dengan menyederhanakan pesan dan mempermudah bahasa.

Penyajian yang kurang menarik bagi siswa mengakibatkan nilai karakteristik menarik dan lugas menjadi tidak optimal. Untuk menyederhanakan dan menarik siswa ke elearning, hal tersebut dilakukan dengan menunjukkan bagian-bagian dari contoh video yang menarik siswa untuk mengaksesnya. Dalam hal interaktivitas, ada kurangnya interaksi antara mahasiswa lain dan dosen. Mengembangkan e-learning memerlukan interaksi antara siswa dan guru, seperti chatting dan diskusi/forum. Seperti yang diinstruksikan oleh para profesional media, media, obrolan, dan diskusi termasuk dalam e-learning tersebut. Beberapa ciri pengembangan situs pembelajaran atau website e-learning antara lain adalah teknik penjelasan yang efektif, transparan, dan mudah dipahami oleh peserta didik melalui gambar, contoh, dan demonstrasi.

Berikut adalah tabel relasi dan tampilan elearning pada mata kuliah logika fuzzy, pada gambar 3 dan 4.

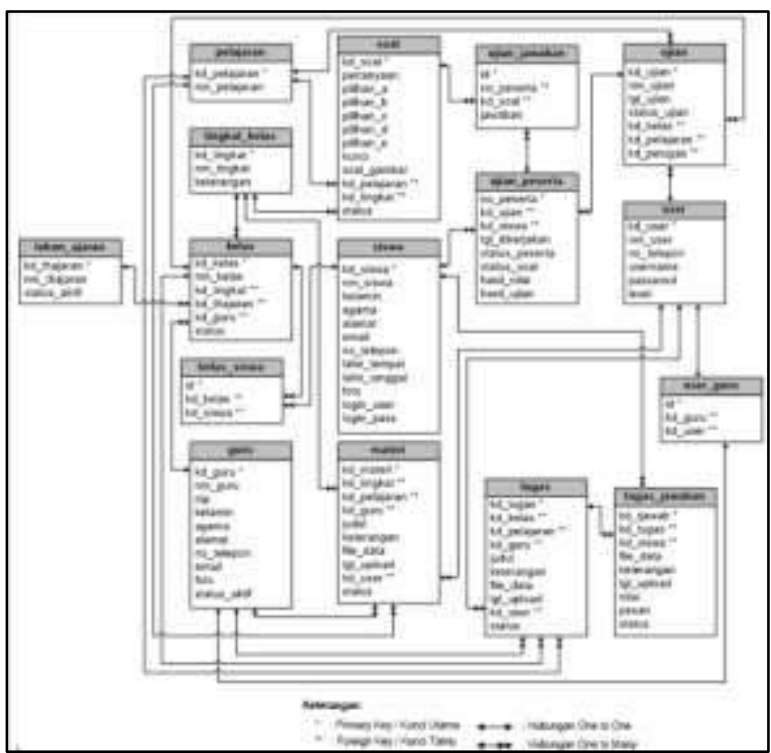

Gambar 4. Hubungan tabel sistem e-learning kursus fuzzy 


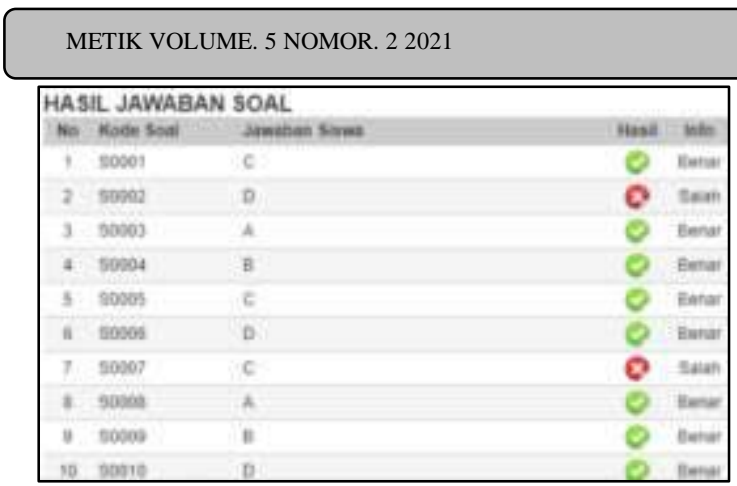

Gambar 5. Tampilan hasil e-learning logika fuzzy (1)

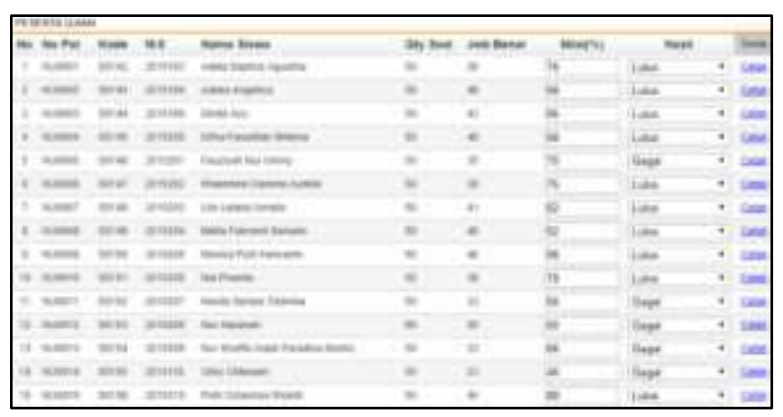

Gambar 6. Tampilan hasil e-learning logika fuzzy (2)

Untuk soal tes atau ujian pada e-learning, kualitas tes dapat diketahui dari validitas dan reliabilitas tes tersebut. Tes harus memenuhi validitas isi berdasarkan standar kompetensi lulusan, standar kompetensi, kompetensi inti atau indikator suatu mata pelajaran untuk mengukur pencapaian kompetensi secara tepat.

$P=\sum \mathrm{B} n$

$\mathrm{P} \quad=$ Tingkat kesulitan

$\sum \mathrm{B}=$ Banyaknya siswa yang menjawab dengan benar

$\mathrm{N}$ = jumlah siswa yang menjawab

\section{Kesimpulan}

Mata kuliah logika fuzzy dengan menggunakan media e-learning dapat lebih interaktif dalam proses pembelajaran, dan dosen mengkonstruksi materi dan pengetahuan. Dalam hal tersebut, pendekatan baru teknologi pembelajaran dapat dikuasai oleh mahasiswa dan dosen dengan sangat baik dan cepat.

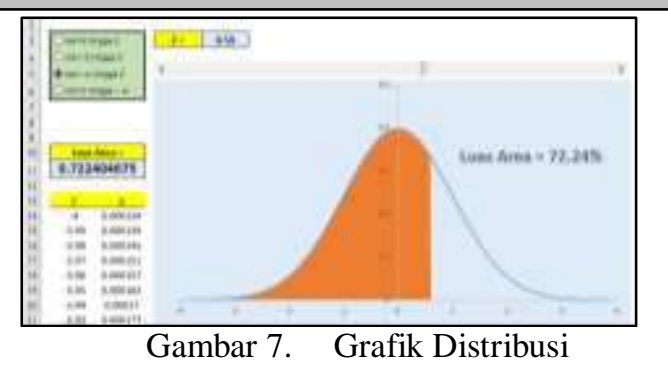

\section{Ucapan Terima Kasih}

Peneliti mengucapkan terima kasih kepada Rektor dan rekan-rekan dosen dari civitas akademika Universitas Mulia, yang telah mendukung dan membantu peneliti dalam melaksanakan penelitian tersebut dan LP3M Universitas Mulia yang telah membina penelitian tersebut hingga selesai. Kami berterima kasih kepada pengelola jurnal dan penerbit atas proses yang dilakukan. Semoga hasil penelitian tersebut dapat bermanfaat dan menjadi referensi bagi peneliti lain.

\section{Daftar Pustaka}

[1] Muhammad Yani, Fahru Rizal, and Muhammad Reza Padillah, "CONTENT MANAGEMENT SYSTEM FOR SCHOOL INFORMATION WEBSITE," MULTICA Sci. Technol., vol. 1, no. 1, 2021, doi: 10.47002/mst.v1i1.203.

[2] Z. Zaini, "MATHEMATICAL REASONING ABILITIES OF STUDENTS IN TERMS OF FIELD DEPENDENCE (FD) COGNITIVE STYLE IN PROBLEM-SOLVING," MULTICA Sci. Technol., vol. 1, no. 1, 2021, doi: 10.47002/mst.v1i1.198.

[3] F. Fathiah, Nelli Raharti, and Muhammad Rizal Fachri, "ANALYSIS OF THE ABILITY OF LECTURERS IN THE USE OF ONLINE LEARNING MEDIA IN THE FACULTY OF TARBIYAH AND KEGURUAN (FTK) UIN ARRANIRY BANDA ACEH," MULTICA Sci. Technol., vol. 1, no. 1, 2021, doi: 10.47002/mst.v1i1.207. 
[4] M. Ula, A. Pratama, Y. Asbar, W. Fuadi, R. Fajri, and R. Hardi, "A New Model of the Student Attendance Monitoring System Using RFID Technology," in Journal of Physics: Conference Series, 2021, vol. 1807, no. 1, doi: 10.1088/17426596/1807/1/012026.

[5] A. S. Pribadi, R. Hardi, Suhartati, R. Kusdyawati, and Sumardi, "ICT Academy at the University," in Journal of Physics: Conference Series, 2021, vol. 1807, no. 1, doi: 10.1088/17426596/1807/1/012036.

[6] H. Richki Hardi, "Pengembangan Sistem Informasi Perpustakaan Menggunakan Kerangka Pieces (Studi Kasus Perpustakaan STITEK Bontang)," Ilm. Teknol. Inf. Terap., vol. 1, no. 3, 2017.

[7] A. Junaidi, I. Kresna A, and R. Hardi, "Analysis of Community Response to Disasters through Twitter Social Media," in Journal of Physics: Conference Series, 2021, vol. 1807, no. 1, doi: 10.1088/17426596/1807/1/012033.

[8] J. F. Rusdi et al., "Collaborative of ICT Research in Indonesia," in Journal of Physics: Conference Series, 2021, vol. 1807 , no. 1, doi: 10.1088/17426596/1807/1/012009.

[9] F. Rizani, "IMAGE QUALITY IMPROVEMENT USING IMAGE PROCESSING METHOD IMAGE BRIGHTNESS CONTRAST AND IMAGE SHARPENING," MULTICA Sci. Technol., vol. 1, no. 1, 2021, doi: 10.47002/mst.v1i1.200.

[10] Gunawan, Sumardi, R. Hardi, Suprijadi, and Y. Servanda,
"Integration of Academic Mobile Applications at University," in Journal of Physics: Conference Series, 2021, vol. 1807, no. 1, doi: 10.1088/17426596/1807/1/012035.

[11] R. Hardi, Gunawan, and Sumardi, "Pendekatan Baru Teknologi Mooc Sebagai Media Pembelajaran Pada Matakuliah Pemrograman," SNITTPolitek. Negeri Balikpapan 2018, 2018.

[12] R. Hardi, "Rancang Bangun Sistem Smart Library pada Perpustakaan SMK Airlangga Balikpapan," JST (Jurnal Sains Ter., vol. 3, no. 2, 2017, doi: 10.32487/jst.v3i2.260.

[13] S. Sigalayan, M. Adriyanto, R. Hardi, J. T. Informatika, and K. Balikpapan, "Sistem Pendukung Keputusan menggunakan Metode TOPSIS dalam Penentuan Pemberdayaan Masyarakat," Seminastika, 2018.

[14] J. F. Rusdi et al., "Reporting of Hospital Facility on Smartphone," in Journal of Physics: Conference Series, 2021, vol. 1807, no. 1, doi: 10.1088/1742-6596/1807/1/012013.

[15] Sri Winar, "AUTOMATIC TRAIN DOOR PORTAL SYSTEM USING REGULATED STRAIGHT MOTION FORMULAS," MULTICA Sci. Technol., vol. 1, no. 1, 2021, doi: 10.47002/mst.v1i1.199.

[16] R. Hardi, "PENGEMBANGAN ANTIVIRUS BERBASIS CLIENT SERVER," Telematika, vol. 12, no. 2, 2015 , doi: 10.31315/telematika.v12i2.1406.

[17] R. Hardi, "Preface," Journal of Physics: Conference Series, vol. 1807, no. 1. 2021, doi: 10.1088/1742- 
6596/1807/1/011001.

[18] R. Rahim et al., "INA-Rxiv: The Missing Puzzle in Indonesia's Scientific Publishing Workflow," in Journal of Physics: Conference Series, 2018, vol. 1007, no. 1, doi: 10.1088/1742-6596/1007/1/012032. 